\title{
Kajian metode penentuan kekuatan momen retak tiang pancang spun pile
}

\author{
Candra Irawan ${ }^{a^{*}}$, I Gusti Putu Raka ${ }^{a}$ dan Priyo Suprobo ${ }^{a}$
}

\begin{abstract}
This paper describes the results of a study carried out experimentally on the determination of the moment strength of spun pile piles. The methods used are visual observation, load-displacement curve evaluation, and tensile strain analysis. The experimental results show that a load of data taken is delayed between 3 and $9 \%$ compared to the results based on loaddisplacement curve. Analysis results from the load-deflection curve is similar to the tensile strain reading in the PC bar. At crack, there exist a sudden jump in the tensile strain of the PC bar where at the same time the stiffness of the load-deflection curve was changed.
\end{abstract}

Keywords: cracking moment, spun pile, visual observation, tensile strain, load-displacement curve.

Abstrak: Makalah ini memaparkan hasil suatu studi eksperimental terhadap perbandingan metode penentuan kekuatan momen retak tiang pancang spun pile. Metode yang digunakan adalah pengamatan visual, evaluasi kurva hubungan beban-lendutan serta analisis regangan tarik. Hasil percobaan menunjukkan besarnya beban retak spun pile dari pengamatan visual tercapai lebih dahulu sekitar 3 hingga $9 \%$ dari hasil pengamatan kurva beban-lendutan. Hasil analisis kurva beban-lendutan hasil yang serupa dengan hasil bacaan regangan tarik PC bar.Pada saat terjadi retak, terjadi loncatan tegangan tarik pada PC bar secara bersamaan dengan terjadinya perubahan kekakuan pada kurva beban-lendutan yang ada.

Kata Kunci: momen retak, spun pile, pengamatan visual, regangan tarik, kurva beban-lendutan.

\section{PENDAHULUAN}

Spun pile merupakan tiang pancang beton pratekan dengan penampang lingkaran berongga seperti ditunjukkan pada Gambar 1. Penggunaan spun pile sebagai pondasi telah banyak dilakukan, baik pada gedung, jembatan, atapun pelabuhan. Sebagai elemen beton pratekan spun pile umumnya didesain sedemikian rupa sehingga gaya prategang menimbulkan tekan pada penampang beton sehingga kapasitas penampang beton dalam menahan tarik menjadi lebih besar dibandingkan dengan beton biasa.

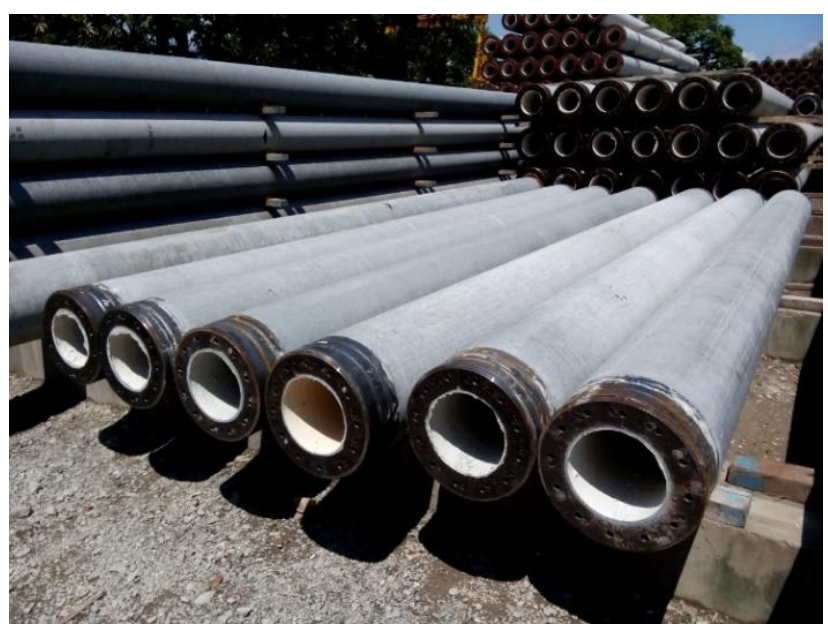

Gambar 1 Tiang pancang spun pile

Akibat beban luar, tiang pancang berperan untuk memikul gaya dalam aksial, momen dan geser. Gaya dalam momen menyebabkan beban lentur pada penampang spun pile. Mekanisme lentur tersebut menyebabkan terjadinya tegangan tekan dan juga tegangan tarik pada penampang

\footnotetext{
Lecturer in the Department of Civil Engineering, Sepuluh Nopember Institute of Technology (ITS), ITS Campus, Sukolilo, Surabaya 60111, Indonesia.

* Corresponding author's email: candra.irawan.its@gmail.com, chandra@ce.its.ac.id
}

tiang. Tegangan tarik yang melebihi batas tegangan tarik tertentu akan menyebabkan penampang tiang mengalami retak. SNI 2847:2019 mengklasifikasikan penampang beton pratekan belum retak pada tegangan tarik di bawah $0,62 \sqrt{f_{c}^{\prime}}$, dalam satuan MPa [1].

Pada lingkungan yang korosi seperti di dekat laut, retak yang terjadi dapat menjadi kritis untuk kinerja jangka panjang walaupun beban yang terjadi masih berada didalam batas beban layan. Oleh karena itu, kekuatan momen retak yang menjadi salah satu variabel yang ditetapkan dalam spesifikasi teknis tiang pancang spun pile harus diperhatikan dengan baik dalam perencanaan.

Ketentuan dalam JIS A 5335 [2] butir 9 tentang 'Inspection' khususnya pada butir 9.3 disebutkan bahwa setiap jumlah produk tertentu dari produksi spun pile, harus dikontrol kuat lentur badan utama tiang (bending strength of main body) yang meliputi momen retak (cracking bending moment ' $\mathrm{M}_{\mathrm{cr}}$ ') dan momen runtuh (breaking bending moment ${ }^{\mathrm{M}} \mathrm{M}_{\mathrm{r}}$ '). Dalam uji laboratorium, penetapan $M_{r}$ relatif mudah. Nilai $M_{r}$ tersebut merupakan nilai momen maksimum yang mampu ditahan benda uji. Sedangkan momen retak merupakan momen saat penampang tiang mulai mengalami retak.

Retak yang terjadi pada beton tarik bisa diamati secara visual. Penetapan ini sesuai ketentuan yang ditetapkan oleh JIS [03] pada butir 3.2.1, secara tekstual berbunyi sebagai berikut "3.2 Bending strength, 3.2.1 Main body. The main body of the PC piles shall be subjected to the bending strength test specified in 8.1 and shall withstand the cracking bending moment given in table 1 without showing any cracks". Sehingga JIS menyarankan penentuan secara visual.

Pengamat retak secara melihat langsung (visual) bersifat subyektif dan berpotensi terjadi keterlambatan dalam pembacaanya jika dilakukan oleh personil yang belum profesional. Penggunaan strain gauge untuk membaca regangan yang terjadi pada tulangan tarik bisa menjadi alternatif untuk menentukan tahap retak pada tiang pancang. Selain itu, penampang tiang yang telah retak 
menyebabkan terjadinya pengurangan inersia penampang yang berakibat pada penurunan kekakuan tiang. Hal ini, bisa dilihat pada perubahan gradien kemiringan kurva beban-lendutan yang menjadi lebih landai akibat retak.

Dalam makalah ini dibahas hasil studi terhadap penentuan kekuatan momen retak tiang pancang spun pile dengan metode pengamatan visual, analisis regangan tarik serta evaluasi kurva hubungan beban-lendutan yang didapatkan dari pengujian eksperimental. Tiang pancang spun pile berdiameter $400 \mathrm{~mm}$ diuji dengan beban lentur sesuai standar JIS. Regangan tarik tulangan prategang dibaca oleh strain gauge. Sedangkan lendutan yang terjadi dibaca oleh transducer (LVDT).

\section{KEPENTINGAN RISET}

Secara kekuatan struktur, retak menyebabkan penurunan kekakuan penampang. Terkait dengan durabilitas struktur, apabila retak yang terjadi mencapai level tulangan maka berpotensi sebagai jalan masuknya klorida ke dalam beton. Apabila retak mencapai tulangan prategang akan terjadi inisiasi korosi yang menyebakan kerusakan tiang pancang. Korosi pada tulangan prategang dapat mengurangi kekuatan beton prategang [3]. Korosi baja tulangan akibat klorida diidentifikasi sebagai salah satu faktor penyebab kerusakan yang paling umum pada struktur beton [4]. Oleh karena itu, penetapan nilai momen retak menjadi penting dalam penilaian untuk menentukan pemenuhan kekuatan spun pile terhadap kebutuhan desain dan aplikasi spun pile di lapangan. Dalam spesifikasi teknis, momen retak merupakan parameter yang ditentukan dalam pemilihan tipe spun pile selain momen ultimit, kapasitas aksial tarik dan tekan [5].

\section{TINJAUAN PUSTAKA}

1. Pengujian Lentur Spun Pile sesuai JIS 53351987 [2] Pembebanan lentur untuk spun pile sesuai JIS ditunjukkan pada Gambar 2. Dari skema pembebanan (load arrangement) tersebut, diperoleh nilai momen lentur tiang adalah:

$$
M=\frac{1}{40} g_{n} m L+\frac{P}{4}\left(\frac{3}{5} L-1\right)
$$

Dimana:

$$
\begin{aligned}
& \mathrm{M}=\text { momen lentur }(\mathrm{kN}-\mathrm{m}) \\
& \mathrm{g}_{\mathrm{n}}=\text { kecepatan gravitasi } 9.81 \mathrm{~m} / \mathrm{s}^{2} \\
& \mathrm{~m}=\text { massa PC-Pile }(\mathrm{kN}) \\
& \mathrm{L}=\text { panjang PC-Pile }(\mathrm{m}) \\
& \mathrm{P}=\text { beban }(\mathrm{kN})
\end{aligned}
$$

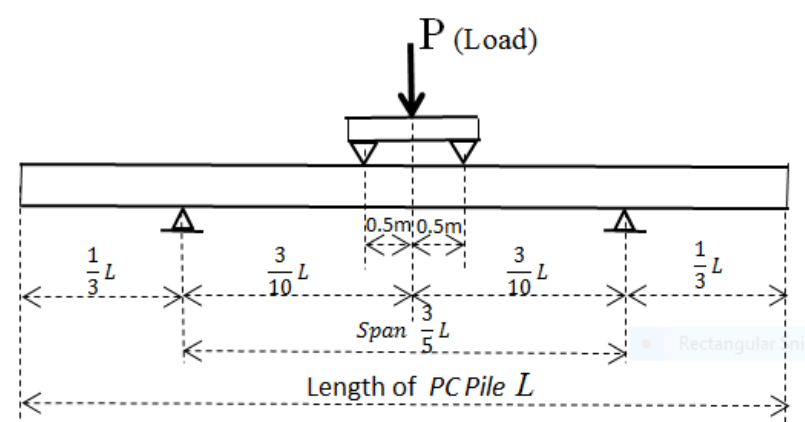

Gambar 2 Skema beban lentur sesuai JIS
Berdasarkan rumus (1) tersebut, momen retak $\left(\mathrm{M}_{\mathrm{cr}}\right)$ dapat dihitung berdasarkan beban retak $\left(\mathrm{P}_{\mathrm{cr}}\right)$ yang langsung didapat saat pengujian dilakukan dengan mensubsitusikan nilai $\mathrm{P}$ dengan $\mathrm{P}_{\mathrm{cr}}$ dan didapatkan $\mathrm{M}_{\mathrm{cr}}$ sama dengan $\mathrm{M}$ pada rumus (1).

Dalam praktek pengujian yang ada, penetapan $\mathrm{P}_{\mathrm{cr}}$ memerlukan kesepakatan terlebih dahulu dari semua pihak yang terlibat, karena pada prakteknya $\mathbf{M}_{\mathrm{cr}}$ yang dimaksud dalam spesifikasi (RKS), bisa bervariasi, berdasar teoritis atau eksperimental. Padahal nilai $\mathrm{M}_{\mathrm{cr}}$ dapat dicari dengan melihat nilai regangan atau tegangan tarik pada serat beton telah melebihi batas kemampuannya. Batasan regangan dan tegangan tersebut dapat dilihat sebagai berikut:

$$
\varepsilon_{c t} \geq \varepsilon_{c r} \text { atau } \sigma_{c t} \geq f_{r}
$$

dimana:

$\varepsilon_{\mathrm{ct}}=$ regangan tarik beton

$\varepsilon_{\mathrm{cr}}=$ regangan retak beton

$\sigma_{\mathrm{ct}}=$ tegangan beton tarik

$\mathrm{f}_{\mathrm{r}}=$ modulus hancur (rupture) beton,

Sesuai SNI 2847-2019 [1], nilai $\mathrm{f}_{\mathrm{r}}$ adalah $0.62 \sqrt{f_{c}^{\prime}}$.

\section{Momen Retak Teoritis}

$$
M_{c r} \geq\left\{\frac{F}{A}+f_{r}\right\} W
$$

dimana:

$$
\begin{aligned}
& \mathrm{M}_{\mathrm{cr}}=\text { momen retak } P C \text { Pile } \\
& \mathrm{F}=\text { gaya prategang; } \\
& \mathrm{A}=\text { luas penampang } \text { PC Pile } \\
& \mathrm{F}_{\mathrm{r}}=\text { modulus runtuh beton } \\
& \mathrm{f}_{\mathrm{c}}=\text { mutu beton; } \\
& \mathrm{W}=\text { momen resisten } P C \text {-Pile }
\end{aligned}
$$

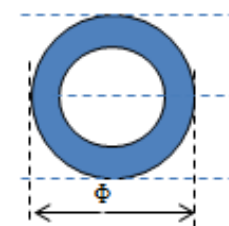

(a)

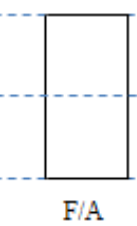

(b)

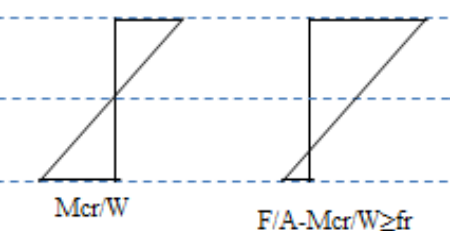

(d)
Gambar 3 (a) Penampang spun pile; (b) Kondisi tegangan beton oleh F/A; (c) Kondisi tegangan beton oleh M/W;

(d) Kondisi tegangan beton serat bawah $\left(\geq f_{r}\right)$

\section{Momen Retak Eksperimental}

Untuk menentukan kondisi retak tiang saat dibebani lentur (Gambar-13), indikasi retak bisa didapat dari tiga katagori: berdasar pengukuran langsung regangan tarik beton $\left(\varepsilon_{\mathrm{ct}}\right)$, lewat pengamatan kurva hubungan antara beban dan lendutan $(\mathrm{P}-\Delta)$ dan lewat pengamatan visual.

Pengukuran kondisi retak tiang dengan menggunakan metode pengukuran langsung $\varepsilon_{\mathrm{ct}}$ dilakukan mengukur perpanjangan atau regangan (epsilon) beton di daerah tarik $\left(\varepsilon_{\mathrm{ct}}\right)$ sehingga kondisi retak dapat ditentukan.

Berdasar kurva kelengkungan atau kurva antara lendutan dengan beban (P- $\Delta$ ), Mcr juga dapat ditentukan. Jika terjadi retak, kurva akan tampak patah (discontinue). Hal ini disebabkan oleh turunnya inersia penampang sehingga lendutan akan bertambah lebih cepat dibandingkan dengan naiknya beban yang ada. Lendutan yang terjadi, dapat diprediksi dengan menggunakan perumusan berikut: 


$$
\Delta=\beta \frac{M L^{2}}{E_{c} I}
$$

dimana:

$$
\begin{array}{ll}
\Delta & =\text { lendutan } \\
\beta & =\text { koefisien tergantung beban } \\
\mathrm{M} & =\text { momen akibat beban } \\
\mathrm{E}_{\mathrm{c}} & =\text { modulus elastisitas beton } \\
\mathrm{I} & =\text { momen inertia benda uji }
\end{array}
$$

\section{Pengujian Lentur Balok Prategang}

Hasil Percobaan pada balok persegi telah dilakukan oleh penelitian sebelumnya [6]. Lima balok diuji lentur dengan skema pembeban dan penampang seperti terlihat dalam Gambar 4, berupa balok berpenampang persegi. Benda uji adalah balok A beton bertulang, balok B, C dan D adalah pratekan parsial 40, 60, $80 \%$ pratekan, sedangkan balok E adalah pratekan penuh.

Skema penempatan alat ukur ditunjukkan pada Gambar 5. Alat yang dipasang adalah pengukur perpendekan serat atas atau tekan dan perpanjangan pada serat bawah atau tarik untuk kedua sisi/muka balok. Selain itu juga dipasang pengukur lendutan/defleksi di sisi bawah.

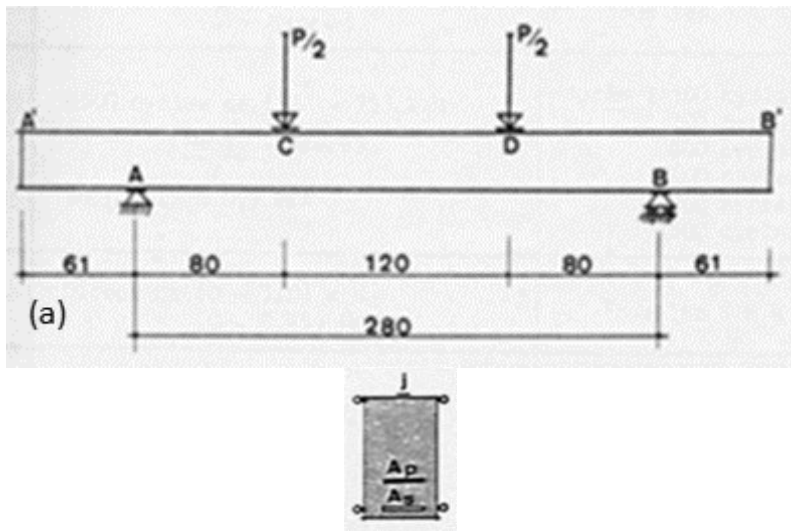

Gambar 4 Skema pembebanan dan penampang balok prategang [6]

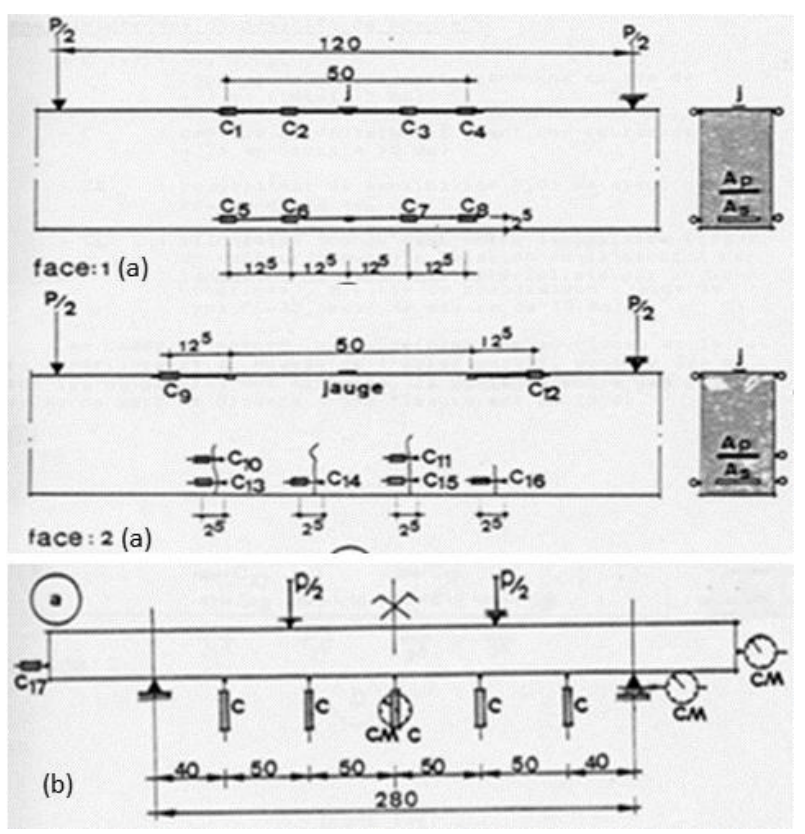

Gambar 5 Instrumentasi pengujian balok [6]
Hasil pengukuran regangan tarik yang terjadi pada serat tarik beton $\varepsilon_{\mathrm{ct}}$ ditunjukkan pada Gambar 6. Kurva tersebut menunjukan hubungan antara $\underline{\varepsilon}_{\mathrm{ct}}$ (regangan serat tarik) dan beban (P). Dari gambar tersebut nampak awal retak sangat jelas bisa ditetapkan berdasarkan loncatan regangan tarik, walaupun hasilnya sedikit berbeda antara kedua sisi balok, namun masih dalam toleransi.

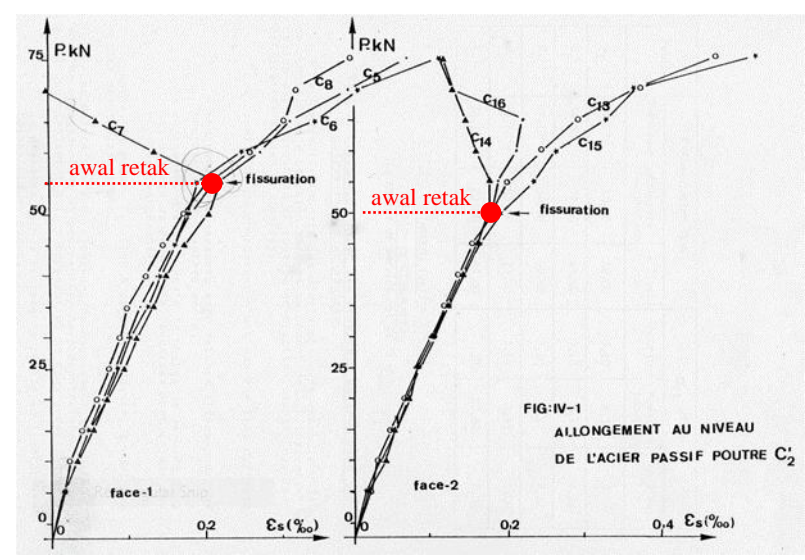

Gambar 6 Hasil pengukuran regangan beton tarik $\left(\varepsilon_{\mathrm{ct}}\right)[6]$

Gambar 7 menunjukan kurva hubungan antara beban dan lendutan untuk seluruh kelima balok balok. Dari kurva ini, awal retak tidak sejelas yang terjadi pada Gambar 6, namun masih dapat dideteksi.

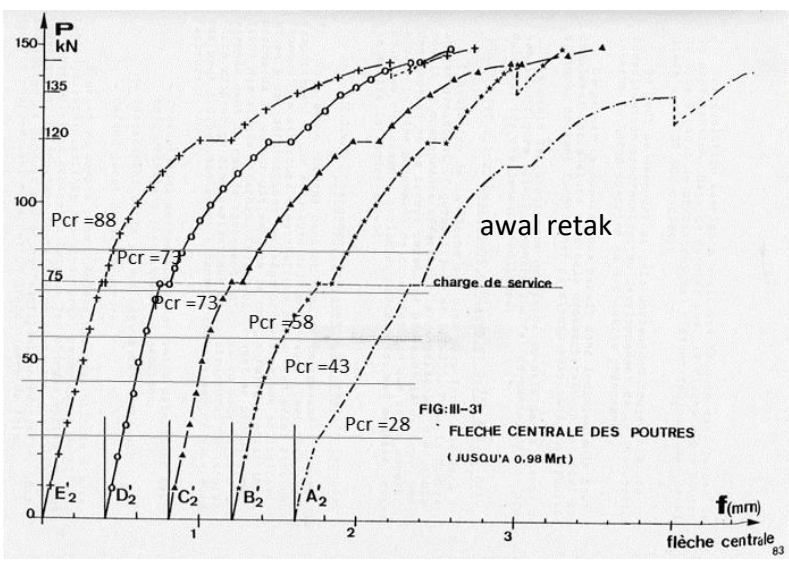

Gambar 7 Hasil pengukuran lendutan di tengah bentang semua balok [6]

\section{METODOLOGI}

Tiang pancang spun pile berdiameter $400 \mathrm{~mm}$ dengan tebal dinding $75 \mathrm{~mm}$ (Gambar 8) dipasangi instrumen strain gauge dengan posisi seperti ditunjukkan pada Gambar 9. Notasi yang digunakan untuk spun pile tersebut adalah $\mathrm{M}$ TB-1, M-TB-2, dan M-TB-3. Pengujian beban lentur monotonik dilakukan dengan pembebanan seperti ditampilkan oleh skema pada Gambar 10. Penentuan retak dilakukan dengan metode pengamatan visual, pengukuran regangan yang terjadi pada tulangan prategang ( $P C$ bar) serat tarik terluar (Gambar 11) dan analisis kurva beban lendutan yang didapatkan dari pembacaan LVDT (Gambar 12). 

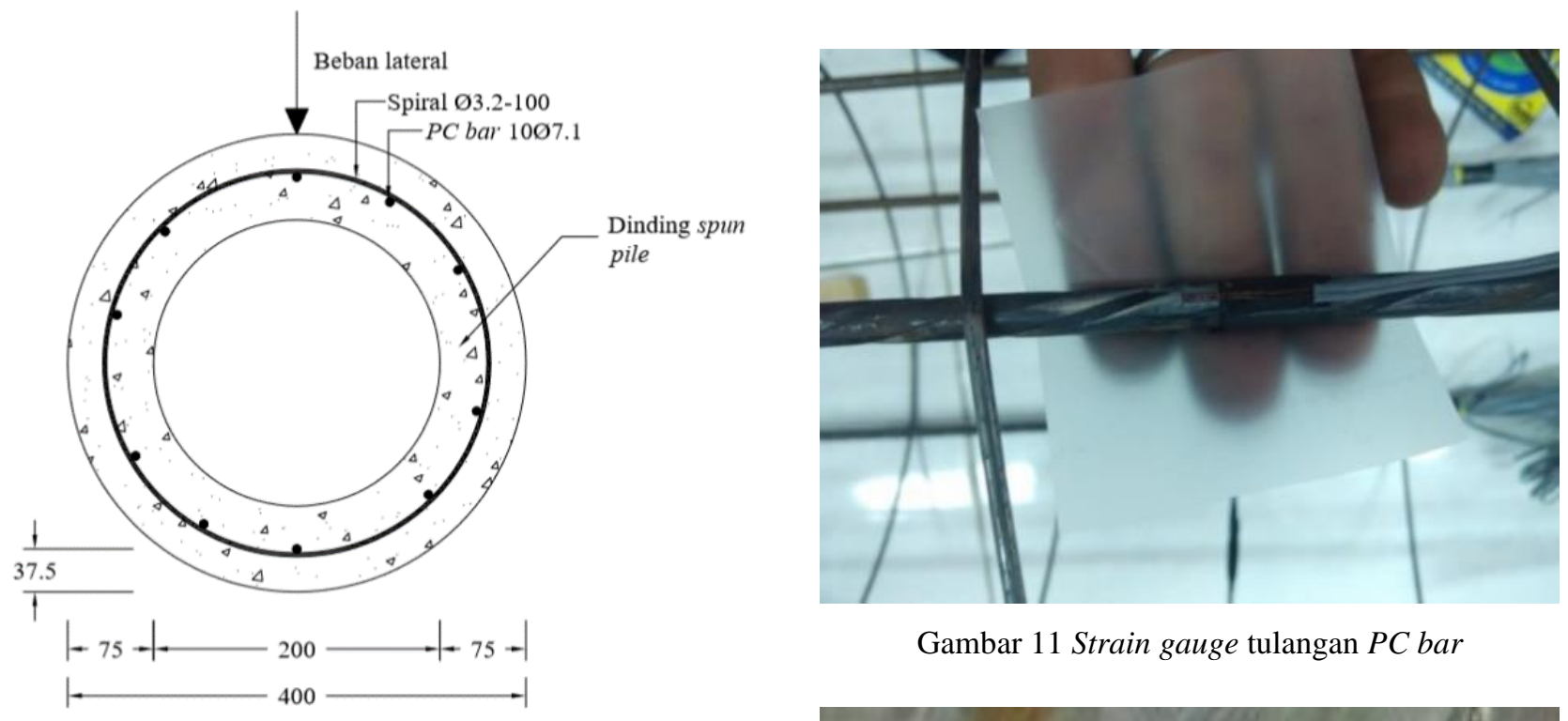

Gambar 11 Strain gauge tulangan PC bar

Gambar 8 Penampang spun pile
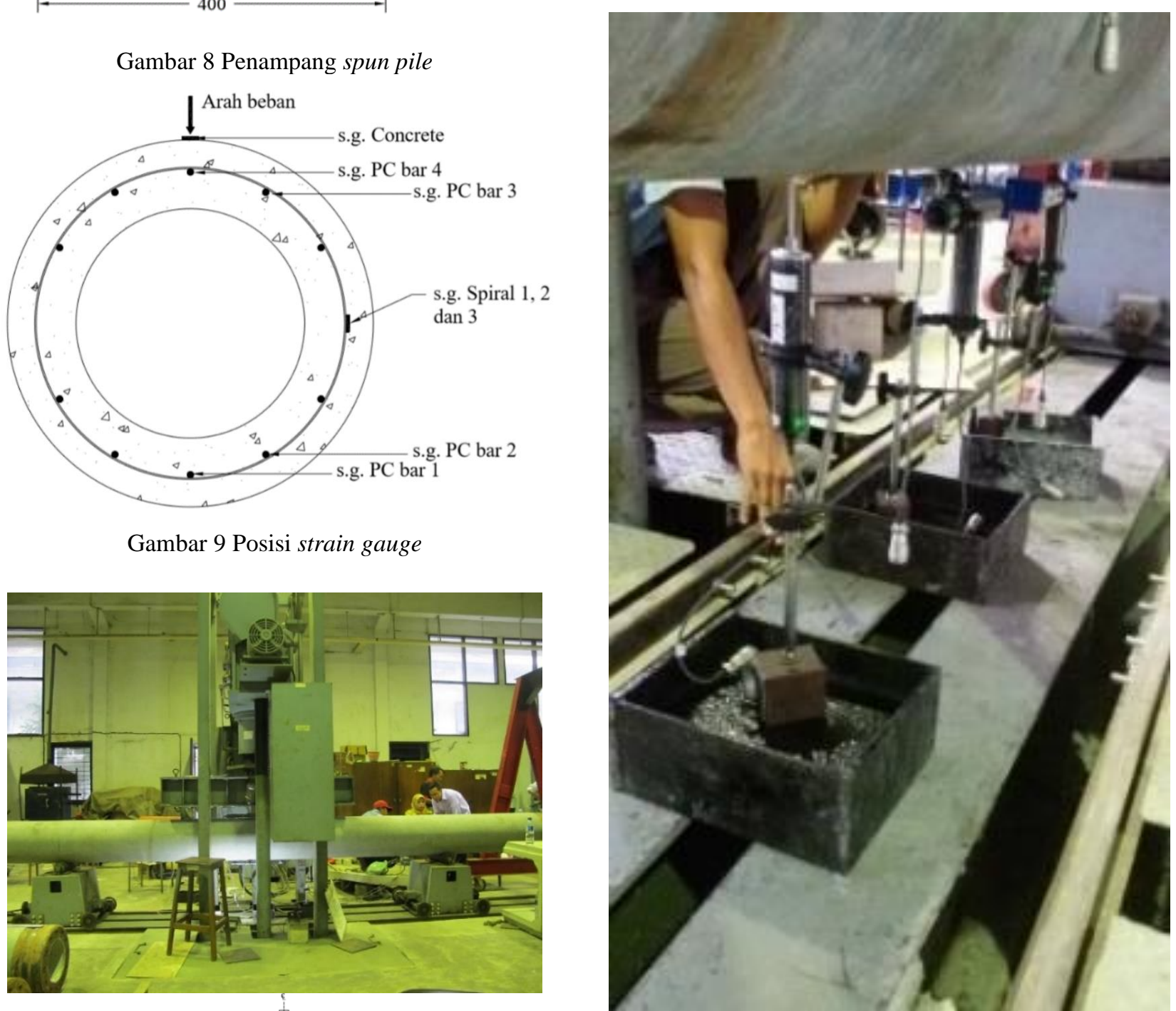

Gambar 12 LVDT vertikal

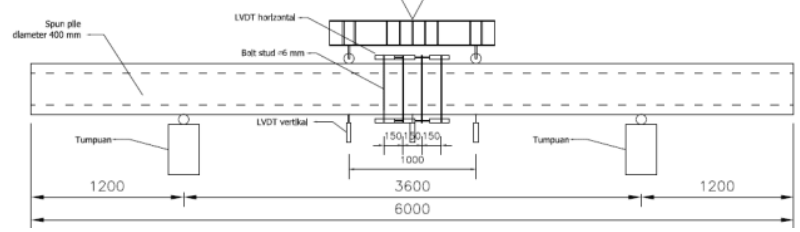

Gambar 10 Set up pembebanan 


\section{ANALISIS DAN PEMBAHASAN}

\section{Pengamatan Visual}

Beban retak hasil pengamatan visual ditulis sesuai dengan hasil pengamatan saat retak pertama muncul. Dari catatan hasil pengamatan beban retak secara visual, besarnya $\mathrm{P}_{\mathrm{cr}}$ untuk masing-masing spun pile dicatat seperti terlihat dalam Gambar 13. Nilai beban retak awal pada spesimen M-TB-1 $\mathrm{P}_{\text {cr }}$ adalah $98 \mathrm{kN}, \mathrm{M}-\mathrm{TB}-2 \mathrm{P}_{\mathrm{cr}}$ adalah 97,5 kN dan M-TB-3 $P_{\text {cr }}$ adalah 97,50 kN. Kondisi visual retak spun pile pada saat beban ultimit ditunjukkan pada Gambar 14.

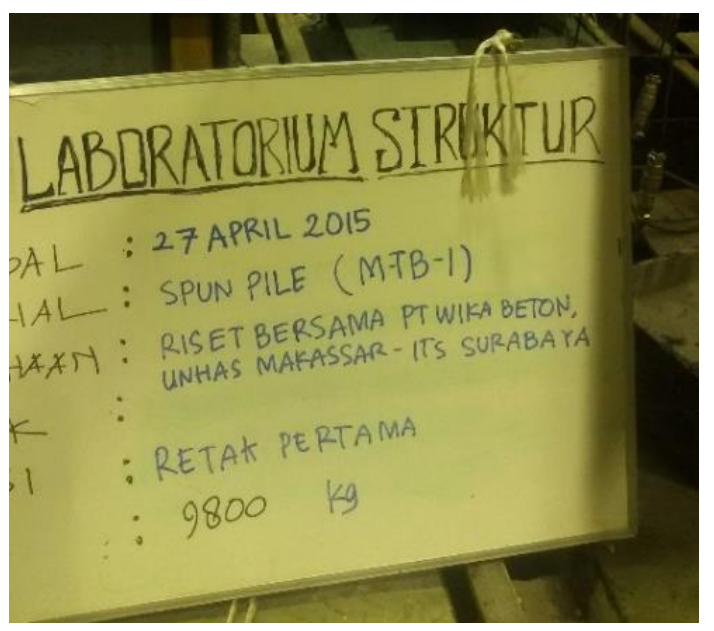

(a) M-TB-1

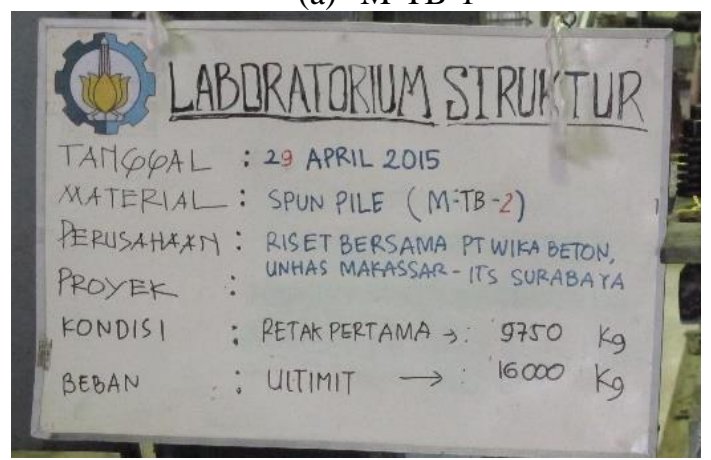

(b) M-TB-2

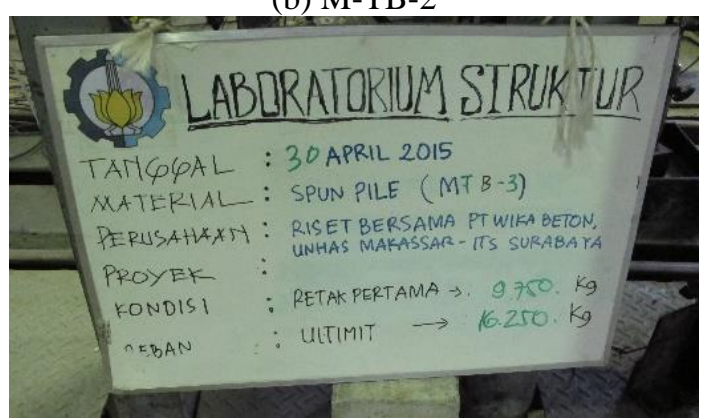

(c) M-TB-3

Gambar 13 Catatan beban retak dan runtuh spun pile

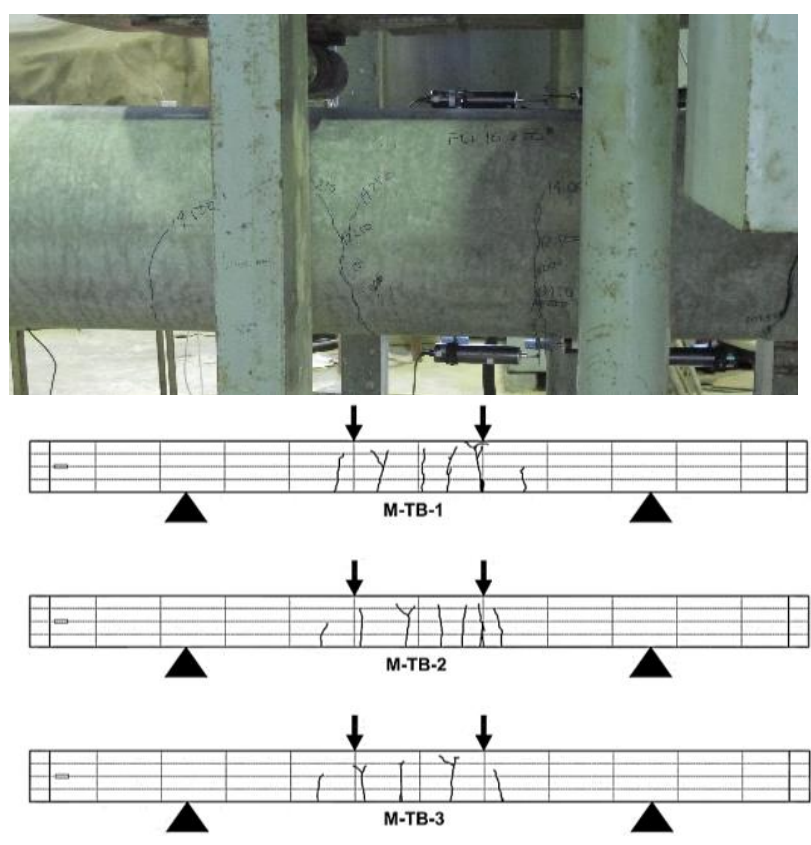

Gambar 14 Kondisi visual retak spun pile $[7,8]$

\section{Hasil pengukuran kurva beban-lendutan}

Terlihat kurva beban perpindahan Gambar 15, pengamatan retak dilakukan dalam rentang lendutan $5 \mathrm{~mm}$. Badan spun pile dinyatakan mulai retak saat terjadi perubahan kemiringan kurva. Benda uji M-TB-1 retak pada beban 93 $\mathrm{kN}$ dengan lendutan 2,7 mm, M-TB-2 retak pada beban 88 $\mathrm{kN}$ dengan lendutan 2,4 mm dan M-TB-3 retak pada beban $93 \mathrm{kN}$ dengan lendutan $2,5 \mathrm{~mm}$.

\section{Hasil pengukuran regangan tarik $P C$ bar}

Akibat beban lentur, $P C$ bar dan beton di bawah sumbu netral akan mengalami tambahan regangan tarik. Seiring dengan bertambahnya beban lentur, dan tegangan yang bekerja mengalami kondisi tarik dan lebih besar dari kapasitas tarik beton, beton akan mengalami retak. Akibatnya, beban tarik yang terjadi pada beton retak akan dipikul oleh tulangan $P C$ bar. Hal ini menyebabkan terjadinya loncatan regangan tarik di $P C$ bar serat tarik terluar. Gambar 16 menunjukkan Riwayat perubahan regangan pada PC bar yang diukur pada ketiga benda uji spun pile. Loncatan regangan tarik terjadi pada lendutan 2,7 mm untuk M-TB-1, lendutan 2,4 mm untuk M-TB-2 dan lendutan 2,5 mm untuk M-TB-3. 


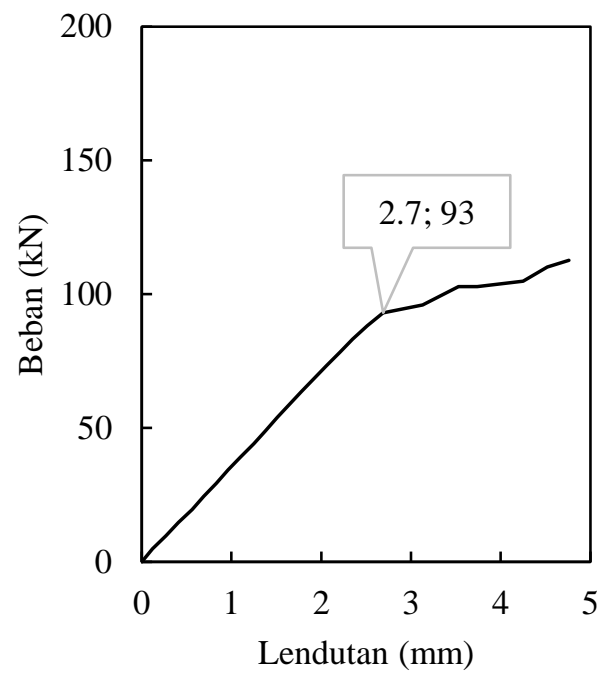

(a) M-TB-1

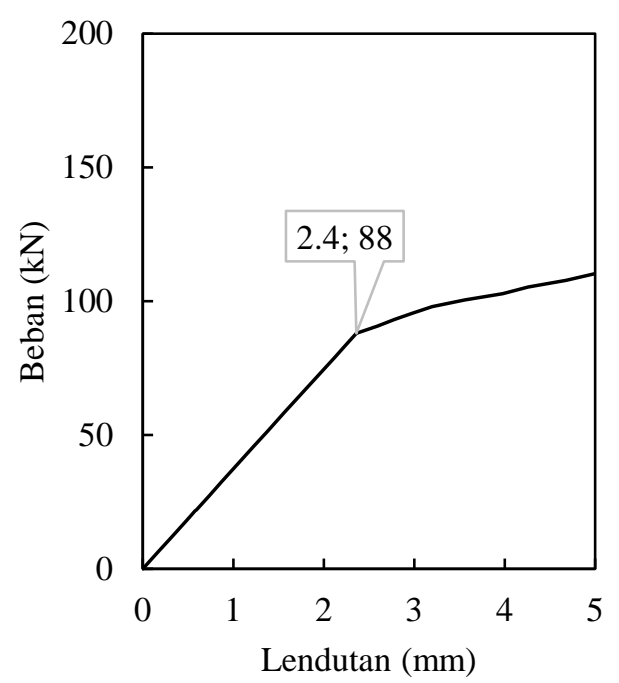

(b) M-TB-2

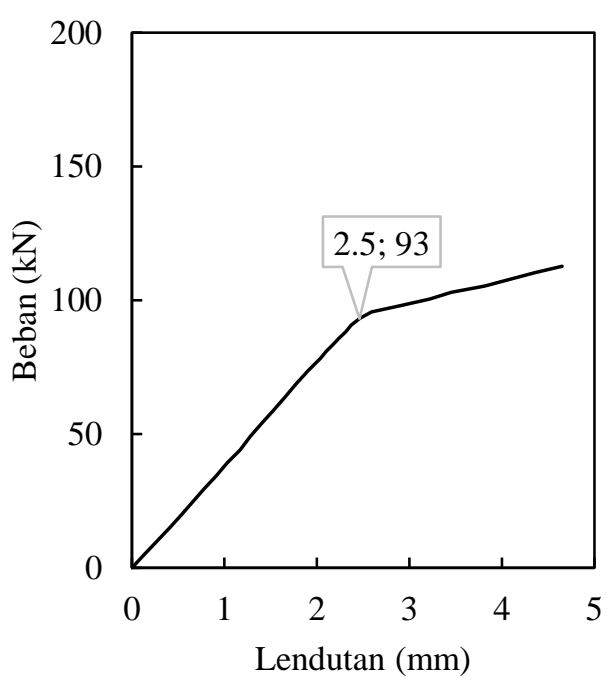

(c) M-TB-3

Gambar 15 Kurva beban-lendutan saat retak

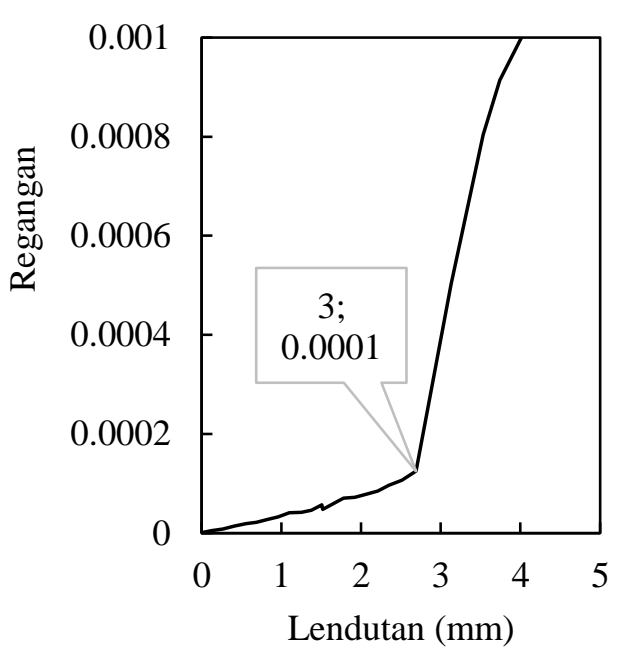

(a) M-TB-1

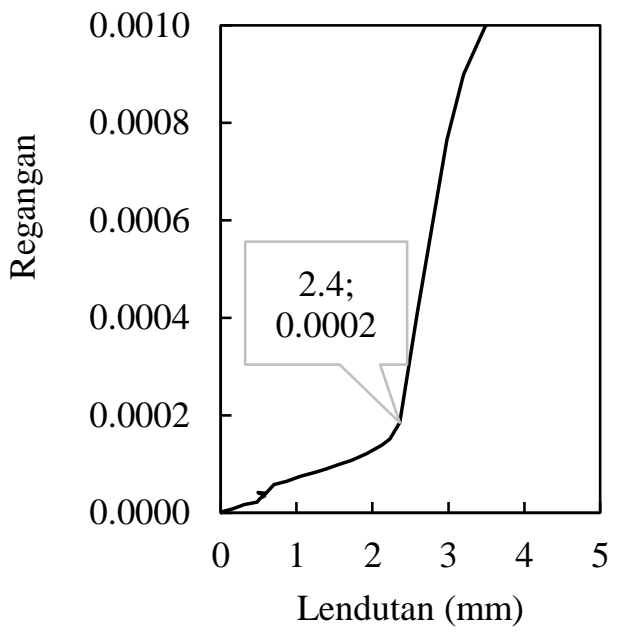

(b) M-TB-2

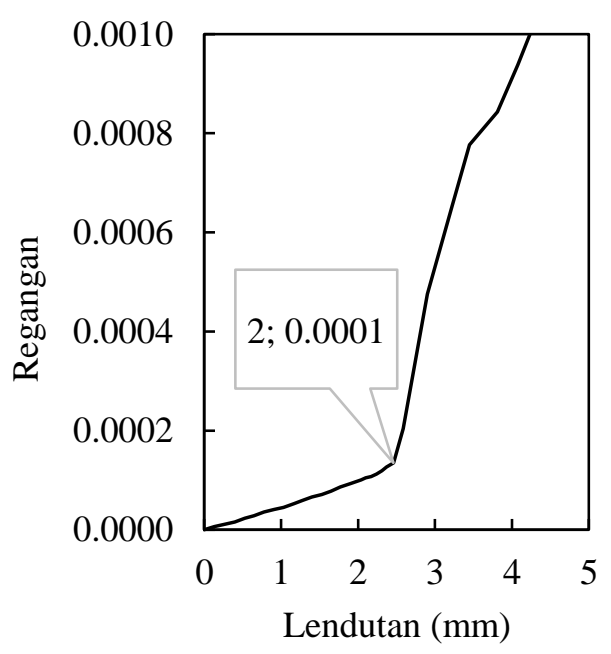

(c) M-TB-3

Gambar 16 Regangan tarik PC bar terluar saat retak 
4. Perbandingan beban retak pengamatan visual, kurva beban-lendutan dan regangan tarik $P C$ bar.

Penentuan beban retak secara visual telah dilakukan dan hasilnya ditunjukkan pada Gambar 13. Analisis kekakuan kurva beban-lendutan ditunjukkan pada Gambar 15. Rekapan beban retak hasil analisis dari kedua metode tersebut ditunjukkan pada Tabel 1. Pada tabel tersebut terlihat beban retak hasil pengamatan visual cenderung lebih besar dibandingkan dengan hasil kurva bebanlendutan dengan selisih hingga $+8 \mathrm{kN}$ seperti pada sampel M-TB-2. Sehingga penentuan momen retak dengan visual terdapat (keterlambatan) delay pembacaan. Secara visual, pembacaan beban retak $(P c r)$ spun pile terlambat sekitar $3 \%$ hingga $9 \%$ dibanding nilai beban retak berdasar kurva beban perpindahan. Delay pembacaan beban retak ini juga terjadi pada pengujian balok prategang yang dilakukan oleh peneliti terdahulu seperti ditampilkan pada Tabel 2 [6].

Tabel 1 Beban retak pengamatan visual dan kurva bebanlendutan

\begin{tabular}{|c|c|c|c|c|c|}
\hline \multirow{3}{*}{$\begin{array}{l}\text { Benda } \\
\text { uji }\end{array}$} & \multicolumn{5}{|c|}{ Beban saat retak } \\
\hline & \multicolumn{2}{|c|}{$\begin{array}{c}\text { Pengamatan } \\
\text { visual }\end{array}$} & \multirow{2}{*}{$\begin{array}{c}\text { Kurva beban- } \\
\text { lendutan }\end{array}$} & \multicolumn{2}{|c|}{$\begin{array}{c}\text { Selisih } \\
\text { visual-kurva }\end{array}$} \\
\hline & $(\mathrm{kg})$ & $(\mathrm{kN})$ & & $(\mathrm{kN})$ & $(\%)$ \\
\hline $\begin{array}{c}\text { M- } \\
\text { TB-1 }\end{array}$ & 9800 & 96,1 & 93 & +3 & +3 \\
\hline $\begin{array}{c}\text { M- } \\
\text { TB-2 }\end{array}$ & 9750 & 95,6 & 88 & +8 & +9 \\
\hline $\begin{array}{c}\text { M- } \\
\text { TB-3 }\end{array}$ & 9750 & 95,6 & 93 & +3 & +3 \\
\hline
\end{tabular}

Jika dibandingkan nilai lendutan saat retak dari kurva beban-lendutan pada Gambar 15 dengan lendutan retak dari regangan tarik $P C$ bar pada Gambar 16, terlihat bahwa nilai lendutan saat retak terjadi pada kurva beban perpindahan sama dengan lendutan saat terjadi peralihan kemiringan kurva regangan. Pada kondisi tersebut, terjadi lendutan sebesar 2,7 mm untuk M-TB-1, 2,4 mm untuk MTB-2, dan 2,5 mm untuk M-TB-3. Dengan demikian nilai beban retak dengan analisis kurva beban-lendutan serupa dengan bacaan regangan tarik $P C$ bar.

Sehingga penentuan beban retak menggunakan kurva beban-lendutan dan rekaman regangan tarik $P C$ bar menghasilkan nilai beban retak yang lebih akurat dibandingkan pengamatan visual.

Tabel 2 Besar $\mathrm{P}_{\mathrm{cr}}$ atas dasar pengukuran regangan tarik beton $\left(\varepsilon_{\mathrm{ct}}\right)$, dan $\mathrm{P}_{\mathrm{cr}}$ atas dasar pengamatan visual pada balok prategang [6].

\begin{tabular}{|c|l|l|l|l|l|c|}
\hline \multicolumn{2}{|c|}{ Tipe Balok } & A & B & C & D & E \\
\hline \multirow{2}{*}{ Pcr(kN) } & Ect & 20.0 & 37.5 & 50.0 & 63.2 & 78.1 \\
\cline { 2 - 7 } & Visual & 28.0 & 43.0 & 58.0 & 73.0 & 88.0 \\
\hline \multicolumn{2}{|c}{ Beda hasil (\%) } & +40 & +14.6 & +16.0 & +10.0 & +7.3 \\
\hline
\end{tabular}

\section{KESIMPULAN}

Penelitian ini memaparkan suatu hasil studi eksperimental terhadap penetapan beban retak tiang pancang pratekan pracetak dengan metode pengamatan visual, analisis regangan tarik, dan evaluasi kurva hubungan bebanlendutan. Berdasarkan penelitian ini dapat diambil beberapa kesimpulan sebagai berikut:
1. Besar beban retak spun pile hasil pengamatan visual $3 \%$ hingga $9 \%$ lebih besar dibandingkan dengan beban retak berdasarkan kurva beban-lendutan. Hal ini menunjukkan terjadi keterlambatan pembacaan data secara visual yang masih dilakukan secara manual dan memerlukan engineering judgement.

2. Penetapan nilai beban retak dengan analisis kurva beban-lendutan serupa dengan bacaan regangan tarik $P C$ bar. Lendutan saat retak berkorelasi basik dengan terjadinya loncatan regangan tarik pada PC bar.

3. Dari ketiga cara penetapan besarnya beban retak, metode dengan menggunakan data kurva bebanlendutan dan bacaan regangan tarik $P C$ bar memiliki tingkat akurasi yang sangat baik.

\section{SARAN}

1. Buat para pelaksana konstruksi, baik perencana, kontraktor maupun pengawas, dianjurkan di dalam dokumen RKS (Rencana Kerja dan Syarat) sebaiknya sudah tidak lagi menggunakan pengamatan secara visual untuk menentukan beban retak yang terjadi. Hal ini dikarenakan penentuan besar beban retak lebih lambat sekitar 3\% hingga 9\% dari bacaan beban retak berdasarkan kurva beban perpindahan yang lebih akurat.

2. Apabila beban retak ditetapkan secara visual (without showing any cracks), maka personil yang ditugaskan haruslah tenaga yang terlatih dan berkomitmen.

3. Penggunaan LVDT di laboratorium untuk menghasilkan kurva beban-lendutan saat pengujian lebih mudah dibandingkan dengan pemasangan strain gauge di dalam benda uji yang harus dilakukan saat produksi tiang pancang. Dengan demikian penggunaan kurva beban-perpindahan menjadi metode penetapan beban retak yang lebih aplikatif dalam pengujian spun pile.

\section{ACKNOWLEDGEMENT}

Ucapan terima kasih disampaikan pada PT Wijaya Karya Beton Tbk. atas kerjasama penelitian spun pile mulai tahun 2014 hingga 2019.

\section{DAFTAR PUSTAKA}

[1] SNI 2847:2019 "Persyaratan beton struktural untuk bangunan gedung". Badan Standardisasi Nasional.

[2] "Japanese Industrial Standard Pretensioned Spun Concrete Piles". JIS A 53351987.

[3] Lizhao Dai, Lei Wang *, Jianren Zhang, Xuhui Zhang (2016) A global model for corrosion-induced cracking in prestressed concrete structures, Engineering Failure Analysis 62, page 263-275.

[4] K. Bhargava, A. Ghosh, Y. Mori, S. Ramanujam, Analytical model for time to cover cracking in RC structures due to rebar corrosion, Nucl. Eng. Des. 236 (2006) 1123-1139.

[5] Brosur Spun Pile produksi PT Wika Beton.

[6] Raka IGP."Contribution a l'Etude du Comportement des Beton Armees Precontraints par fils adherents soumises a des Chargements Cycliques". These de Doctor-Ingeneur, presentee a l'Institut National des 
Sciences Appliquees de Toulouse. Soutenue le 12 Janvier 1982.

[7] Irawan, C., Djamaluddin, R.; Raka, IGP.; and Suprobo, P., October 2016. "The Experimental Investigation of Failure Mechanism of Spun Pile due to Monotonic Loading using NEHRP 2000". 4th International Conference on Protective Structures (ICPS4).

[8] Irawan C, Djamaluddin R, Raka IGP, Faimun, Suprobo P.,Gambiro. "Concrete on flexure performance of spun pile-an experimental study". Jurnal Teknologi (Sciences \& Engeneering), 78:1 (2016) $1-5$ 